\title{
The Trade-Labour Nexus: \\ Global Value Chains and Labour Provisions in European Union Free Trade Agreements
}

\author{
Mirela Barbu, Queen Mary University, United Kingdom \\ Liam Campling, Queen Mary University, United Kingdom \\ Adrian Smith, Queen Mary University, United Kingdom \\ James Harrison, Warwick University, United Kingdom \\ Ben Richardson, Warwick University, United Kingdom
}

\begin{abstract}
Labour standards provisions contained within the European Union's (EU) free trade agreements (FTAs) are a major iteration of attempts to regulate working conditions in the global economy. This article develops an analysis of how the legal and institutional mechanisms established by these FTAs intersect with global value chain governance dynamics in countries with contrasting political economies. The article formulates an original analytical framework to explore how governance arrangements and power relations between lead firms in core markets and suppliers in FTA signatory countries shape and constrain the effectiveness of labour provisions in FTAs. This analysis demonstrates how the common framework of labour provisions in EU trade agreements, when applied in a uniform manner across differentiated political-economic contexts, face serious difficulties in creating meaningful change for workers in global value chains.
\end{abstract}

\section{KEYWORDS}

Labour provisions; free trade agreements; global value chains; European Union

\section{Introduction: The Rise of Labour Provisions in European Union Free Trade Agreements}

Over the last decade, the European Union (EU) has included labour provisions in its preferential trade agreements in an attempt to govern working conditions in the world economy (Van den Putte, 2015; Van den Putte and Orbie, 2015; Campling, Harrison, Richardson and Smith, 2016). This adds to a landscape of global labour governance that includes private standards and codes of conduct (Locke, 2013), international labour law in the form of International Labour Organization (ILO) conventions, and other trade agreement labour provisions approaches, such as those found in United States (US) trade agreements since the North American Free Trade Agreement (NAFTA) (Alston, 2004; Tran, Bair and Werner, 2017). Research on the effectiveness of private labour standards has tended to argue that public regulation is a necessary complement (e.g. Locke, Rissing and Pal, 2013), while research on international labour rights has recognised the value of inscribing them into commercial agreements and using economic incentives to help implement them (Compa, 2001). In this respect, the proliferation of labour provisions in international trade agreements might suggest a progressive advance in global labour governance. The ILO (2016) found that 28 per cent 
of preferential trade agreements recognised by the World Trade Organization (WTO) contain labour provisions and that the number has been increasing in recent years. Over 80 per cent of preferential trade agreements that came into force since 2013, the majority of which have been bilateral free trade agreements (FTAs), have included such provisions. This signals a burgeoning attempt to govern working conditions in the world economy via mechanisms established to foster increasing economic integration. While it is recognised that FTAs are increasingly important in the deepening of inter-firm relations within global value chains (GVCs) (Barrientos, Mayer, Pickles and Posthuma, 2011), ${ }^{1}$ we focus here on the novel way in which trade policy uses labour provisions to regulate working conditions. This requires understanding their role in shaping national regulatory frameworks as well as dynamics of supply chain governance. We call this attempt to govern working conditions and labour via trade policy and deepening value chain integration the "tradelabour nexus". Given this rise of labour provisions in FTAs, it is of intrinsic political and analytical importance to better understand them as an emerging form of international labour governance. Yet, despite the proliferation of FTAs in a world economy increasingly characterised by global value chains, few studies on the trade-labour nexus have thus far developed a framework to explore the extent to which labour provisions in FTAs enhance working conditions in GVCs (see Smith et al., 2018). The principal contribution of this article is to advance such a framework. We do so by reference to brief illustrative empirical examples drawn from research on the implementation of labour provisions in two recent FTAs. These examples are not provided as detailed case studies but as illustrative vignettes to amplify the key themes of the framework which the article establishes.

\section{Labour Provisions, EU Trade Agreements and Global Value Chains}

The European Commission's 2015 Trade for All strategy recognises the centrality of global supply chain integration to its trade liberalisation agenda, and ties this to the agenda of "sustainable development", including the promotion of higher labour and environmental standards. The Trade for All strategy normatively argues for the need to promote what it identifies as a set of "European values" through trade policy (European Commission, 2015: 20-26; see also Manners, 2002, on normative power). ${ }^{2}$ The strategy makes it clear that all European Union FTAs will include elements related to sustainable development, human rights, fair and ethical trade, the fight against corruption, and good governance (European Commission, 2015: 22-26). As part of this agenda, a new three-way relationship is articulated between trade policy, sustainable development and global value chains (European Commission, 2015: 5). These seek to achieve the "responsible management" of global value chains and mirror the wider engagement of international economic and development policy-making communities with the concept of GVCs (Neilsen, 2014; Werner,

\footnotetext{
${ }^{1}$ We do not assume that an FTA necessarily results in more integration of GVC governance. As we shall see, FTAs may or may not create incentives for lead firms to become territorially embedded in a particular place, which may create greater or fewer resources for workers to leverage this embeddedness. Contrast, for example, Liu and Dicken (2006) on the "obligated embeddedness" of market-seeking foreign direct investment by automotive manufacturers in China, which is independent of any FTA, with the resourceseeking investment in canned tuna production in Papua New Guinea which is dependent on FTA tariff preferences with the EU and which enhanced the capacity of organised labour to leverage the social clauses of the FTA to improve their conditions (Campling et al., 2016).

2 It is unclear as to why the "values" identified in the strategy are specifically "European" rather than universal. However, they reflect wider concerns over developing a "European social model", which refers to the social dimension of the EU's internal market. The EU's external trade policy after 2011 is an attempt to externalise this dimension through trade agreements.
} 
Bair and Ramiro Fernández, 2014; Stephenson, 2016). A key element of the EU's approach has been to embed labour provisions within a Trade and Sustainable Development (TSD) chapter in each of the so-called "new generation" trade agreements since 2009 when the EU-South Korea FTA negotiations ended (ILO, 2013; Campling et al., 2016). Overall, the European Commission argues that trade agreements, and the labour provisions contained within them, can play an important role as "levers" to create greater responsibility in supply chains (Malmström, 2015; European Commission, 2015: 5).

The inclusion of labour provisions in EU FTAs has stimulated much research, chiefly on the internal policy-making process that has produced this particular approach to international trade. Yet, while TSD chapters in EU FTAs provide an important precedent and early exemplar of the EU's Trade for All strategy, there is an analytical gap in evaluating the effectiveness of this approach to enhance labour and environmental standards in global value chains. On the one hand, there is a growing literature assessing the impact of the EU's approach to trade and sustainable development via the institutional and legal governance arrangements established in the agreements (Postnikov and Bastiaens, 2014; Van den Putte, 2015; Campling et al., 2016; ILO, 2016). ${ }^{3}$ On the other hand, there has been a recent policy evaluation report, funded by the European Commission, of what is generally regarded as the flagship initial agreement, the EU-Korea FTA (Civic Consulting and Ifo Institute, 2017). However, this body of work has yet to consider analytically the influence of power relations between lead firms and supplier firms in the governance of labour standards and their (dis)articulation with the labour provisions. While value chain integration can deepen through trade liberalisation, and articulates with national and local regulatory labour regimes, the power relations between lead and supplier firms can also set structural limits to the possibilities for improvements in labour standards and working conditions (Smith et al., 2018). Analytically, then, we develop a framework seeking to bring these dynamics together. With supplier firms under considerable cost pressure around the world economy, the "business space" for enhancements in working conditions may be very limited, or even non-existent in certain contexts, thereby setting serious limits on the ability of the EU's approach to TSD to enable improvements in working conditions in its trading partners. The primary argument of the article is that understanding the extent to which labour standards clauses in FTAs can be effective mechanisms for enhancing working conditions requires that analytical attention is paid to inter-firm power relations in global value chains, which are simultaneously shaped by the liberalisation of trade via FTAs, and their intersections with national regulatory contexts and local labour regimes. As is well established in the literature on GVCs, these power relations structure the range of possibilities for action to improve labour standards by supplier firms in partner countries. What is less well understood is that such inter-firm relations set material limits to the extent to which the new regimes of labour governance through FTAs are able to address actual working conditions; these are regimes that rely primarily on ILO conventions and declarations. Pointing in this direction, Anner, Bair and Blasi (2013) identify how the (low) contract prices paid to suppliers are considered to be "the root cause" of poor working conditions in buyerdriven chains, but which are not targeted directly by the core labour standards embodied in the ILO fundamental conventions. Relatedly, Hauf (2015) examines the failure of the ILO decent work agenda to recognise the structural causes of poor working conditions.

The potential for labour standards clauses contained in FTAs to drive progressive change in working conditions is, we argue, differentiated on the basis of three primary forces: (a) the geopolitical contexts involved, including the relative balance of commercial or other interests in establishing a trade agreement with the EU; (b) the national political economy of multi-scalar

\footnotetext{
${ }^{3}$ We provide a fuller assessment of these various literatures later in the article.
} 
labour regimes at national and local levels and the regulatory frameworks established by states; and (c) the power relations that supplier firms are integrated into (that is, where a firm sits in the value chain or production network). ${ }^{4}$ The article sets out an analytical framework that combines these three forces, which we illustrate via brief empirical vignettes. We argue that lead firm pressures, which can be deepened by trade integration, shape and potentially limit the possibilities for improvements in labour standards, which FTAs claim to seek to achieve via institutional means. The degree to which each of these three forces intersect in shaping particular local outcomes in a state which has signed an FTA with the EU is a contingent question related to the particular conjunctural dimensions of political forces, sectoral foci and labour politics in each case. Methodologically, our framework is a "way in" to identifying those factors that matter most in the actual uptake of labour standards (i.e. a tool for those who want to study labour standards in trade agreements). Politically, it advances a critique of those policy-makers and academics who rely on legal provisions alone as a necessary and sufficient form of protection for workers' rights in the context of the intensified economic conditions that tend to accompany FTAs, indeed, which are incorporated into their very design.

In making this argument we draw upon the expanding body of research focusing on the relationship between global value chains, global production networks (GPNs), and labour processes (Barrientos et al., 2011; Newsome, Taylor, Bair and Rainnee, 2015; Pattenden, 2016; Baglioni, 2018; Smith et al., 2018). We demonstrate that, if labour provisions in FTAs are going to become a meaningful labour governance mechanism, they need to take into account the differentiated inter-firm governance regimes and power relations across different GVCs. This argument has already been firmly established in the literature on the private ordering of labour standards such as via corporate codes of conduct and policies on corporate social responsibility (CSR) (Locke, 2013). As such, it is worth noting why FTAs and trade agreements more generally are an important "case" for consideration beyond their rapid quantitative increase. FTAs are state regulatory forms, and the labour standards contained within them are politically oriented to domestic democratic constituencies in the EU and North America (not end-consumers or buyers as in the case of private ordering). As we will argue in the next section, the emergence and proliferation of labour provisions in the 2000s can be explained through the interplay of "topdown" and "bottom-up" social and political forces in the 1990s. As inter-state regulation, the mechanisms of labour standards governance in FTAs are different in form (if not substance) to those in the private ordering of labour in GVCs (Mayer and Phillips, 2017). We do, however, note an important analytical caveat: we are not advancing a perspective that reproduces a hard distinction between public and private regulation. Indeed, we see them as profoundly intertwined, including in and through GVCs. Moreover, GVCs themselves "arise as firms engage dynamically with multiple, overlapping and often conflicting local, national, regional and transnational legal regimes, soft law normative orders and private ordering mechanisms" (Law and Global Production Working Group, 2016: 58).

The rest of the article is organised into four sections. The next section sketches the rise of the trade-labour nexus in bilateral FTAs in the context of social struggles over globalisation. This is followed by a section setting out the key dimensions of the EU's approach to including labour provisions in its FTAs, and exploring existing approaches to assessing the impacts on labour

\footnotetext{
${ }^{4}$ While we make particular reference to EU examples, our conceptual framework would apply equally well to other FTAs and GVCs, such as in a US-centred analysis. There are important differences between the two in terms of labour standards governances, with the US approach being more conditional and the EU's more promotional.
} 
standards provisions in free trade agreements. A third section establishes an analytical framework for understanding the limits to and scope for labour governance via labour provisions in FTAs. We then conclude with some reflections on the structure of labour provisions in FTAs.

\section{Labour Provisions in Bilateral FTAs: The Trade-Labour Nexus}

The relationship between global economic integration and international trade policy has been an important focus for parts of the research literature on GVCs and GPNs (Gereffi, 1994; Spener, Gereffi and Bair, 2002; Gibbon and Ponte, 2005; Coe and Yeung, 2015; Curran, 2015; Curran and Nadvi, 2015; Smith, 2015a,b; Campling, 2016). However, very little attention has been paid in this body of work to the use of labour provisions in FTAs as a mechanism of global labour governance. This absence of analytical work seeking to examine the articulation of trade, global value chains and labour governance in trade agreements is striking given the proliferation of labour provisions in such agreements. Canada, the EU and the US have been the most active in promoting labour provisions, albeit adopting two broadly contrasting approaches. Agreements concluded by Canada and the US invariably include a conditional element where non-compliance with labour standards can entail some kind of fine or trade sanction. By contrast, since the late 2000s the EU has adopted a trade policy approach to labour provisions centred on dialogue and promotion of ILO core labour standards (ILO, 2013; Campling et al., 2016), providing a framework for engaging civil society groups in monitoring and cooperation around "sustainable development", of which labour standards are one part. ${ }^{5}$

How did this increasing use of labour provisions in bilateral FTAs come about? While it is difficult methodologically to always clearly identify cause and effect in trade agreements and changes to labour standards and working conditions, an explicit justification for the rising discourse in the 1990s on introducing labour provisions in trade agreements was (and is) to address the question of winners and losers from economic liberalisation, especially impacts on workers of opening trade. However, the failure to negotiate labour provisions in the multilateral trade system during the WTO Uruguay Round in 1994, followed by a second unsuccessful attempt during the WTO Singapore Ministerial Conference in 1996, reflected widespread anxiety among many developing country governments concerning the potential protectionist nature of social clauses in multilateral trade regimes (Haworth and Hughes, 1997; Wilkinson and Hughes, 2000; Tsogas, 2001). The primary response to this failure to establish a multilateral system of trade and labour governance has been an increase in labour provisions in bilateral trade agreements as an attempt to channel the economic benefits of liberalisation into social rights and to counter the race-to-thebottom hypothesis (Tsogas, 2001; ILO, 2016).

Vital context to the introduction of labour provisions in trade arrangements were the "bottom-up" social movements of the late 1990s and early 2000s. These targeted exactly the "top down" liberal project of global economic governance as epitomised by the WTO, the International Monetary Fund (IMF), the G7, and other agencies of the perceived transnational elite. A central criticism by the global justice movement was of secretive, pro-corporate trade liberalisation, which, as the slogan suggests, "put people before profit" and proliferated precarious employment (Bove, Murgia and Armano, 2017). The movement was most prominent publicly when protesting against meetings of global elites and coordinating simultaneous demonstrations in cities throughout the

\footnotetext{
${ }^{5}$ Labour provisions are included alongside international environmental provisions in all EU agreements except the Comprehensive Economic and Trade Agreement (CETA) where they comprise separate chapters.
} 
world - putting into being the movement's mantra, "our resistance will be as transnational as capital" (Routledge, 2000). These protests received considerable media attention, such as the 1999 "Battle of Seattle", and provided impetus for deepening networks among otherwise disparate groups of activists representing a diversity of concerns - the so-called "movement of movements" - including labour, the environment and development (Notes from Nowhere, 2003). ${ }^{6}$ By the late 1990s, a powerful new rapprochement was emerging between labour movements and the new social movements (Della Porta, 2005). The World Social Forum was established in this conjuncture as a civil society response ${ }^{7}$ to global meetings of states and capital such as at the World Economic Forum and Davos. In this dynamic context, parallel social movements were heightening their focus on the specific issue of sweatshop labour - most notably in the global clothing industry (Hale, 2005). ${ }^{8}$ The industry was seeing increasing global reach via trade liberalisation and the end of the quota-constrained trade regime of the Multi-Fibre Arrangement (Pickles and Smith, 2016); clothing and footwear branded firms were the corporate vanguards of codes of conduct on labour standards, including commitments not to source from factories where "sweat shop" working conditions are prevalent (Locke, 2013).

These social forces of bottom-up global governance provided the context within which pressure on state managers wanting to establish international trade arrangements, including within the EU, developed to take a more a holistic approach to trade such as the incorporation of sustainable development. This much was apparent at the WTO in 2001 with the incorporation of "development" front and centre in the Doha Round. For the first time in the history of the GATT/WTO, negotiations were initiated on particular trade rules that commenced with development and environment considerations rather than these being tagged on at the end (Campling and Havice, 2013). This has contemporary parallels in the opposition to the Transatlantic Trade and Investment Partnership (TTIP) by social movements and labour organisations in Europe and the US. ${ }^{9}$ The European Commission responded by introducing unprecedented levels of transparency into the negotiation process (European Commission, 2014), which for some, including Members of the European Parliament, remained insufficient (Giegold, 2015). European Commission transparency was also about countering pressure from EU labour and other social movements concerned with the possible downgrading of EU social standards via TTIP. Across the Atlantic, one of the first acts of the Trump Administration was to pull back from macro-regional FTAs because of perceived negative impacts on US-based labour. This move saw Trump tapping into the zeitgeist of anti-FTA social movements and a considerable minority of popular opposition to TTIP (Bluth, 2016), to the Trans-Pacific Partnership and to the North American Free Trade Agreement. In sum, while the trade-labour nexus is often seen as a technocractic form of labour governance from above, the global justice movement provided the political conditions for the emergence of labour provisions in FTAs, even if not all elements of the movement endorsed them. In the European Union, they arose in the context of the European Commission seeking to counter criticisms by the incorporation of civil society in its TSD chapters.

\footnotetext{
6 The "Teamsters and Turtles" in the US context (Berg, 2003).

${ }^{7}$ Here "civil society" expressly does not include business groups, in direct contrast to the EU's use of the term (see below).

${ }^{8}$ For example, the Clean Clothes Campaign, No Sweat, Labour Behind the Label, Women Working Worldwide, to name a few.
}

${ }^{9}$ Most prominently the Stop-TTIP campaign - a coalition of over 500 European civil society organisations. 


\section{The EU's Approach to Labour Provisions in Bilateral FTAs}

Within this context the EU has focused its energies on the development of an emerging "blueprint" for the inclusion of labour provisions in its bilateral FTAs (Van den Putte, Bossuyt, Orbie and De Ville, 2013; Campling et al., 2016). As noted above, each of the EU's recently negotiated FTAs contains a TSD chapter (or separate chapters) encompassing both labour and environmental matters. These include substantive legal obligations and institutional mechanisms designed to oversee issues of trade and labour governance - at the heart of which is a procedural commitment to engage with civil society organisations in the monitoring of these issues (summarised in Table 1$).^{10}$

Table 1: Key provisions and institutional mechanisms included in TSD chapters

\begin{tabular}{|c|c|}
\hline Provisions and mechanisms & Formulation in the TSD chapters of EU FTAs \\
\hline 1. Substantive standards & $\begin{array}{l}\text { Requirement to meet or progressively implement core labour } \\
\text { standards as embodied in the ILO fundamental conventions and } \\
\text { recognise the ILO Decent Work Agenda rights and principles as } \\
\text { referred to in: } \\
\text { - the ILO Declaration of Fundamental Principles and Rights } \\
\text { to Work from } 1998 \text { and its follow-up } \\
\text { - the UN Economic and Social Council on Full Employment } \\
\text { and Decent Work for All from } 2006 \\
\text { the ILO Declaration on Social Justice for a Fair } \\
\text { Globalization from } 2008\end{array}$ \\
\hline 2. Procedural commitments & $\begin{array}{ll} & \text { Transparency } \\
\text { - } & \text { Dialogue } \\
\text { - } & \text { Cooperation } \\
\text { - } & \text { Commitment to impact assessment } \\
\end{array}$ \\
\hline 3. Institutional mechanisms & $\begin{array}{l}\text { - } \text { Trade and sustainable development sub-committees } \\
\text { - } \text { Domestic advisory groups } \\
\text { - } \text { Civil society fora } \\
\text { - } \quad \text { Panel of experts }\end{array}$ \\
\hline
\end{tabular}

The substantive legal obligations of labour governance in FTAs relate to upholding the ILO core labour standards that have been ratified by the parties. These include the eight "fundamental conventions" covering freedom of association and collective bargaining, forced labour, child labour and non-discrimination. ${ }^{11}$ There is some variance in the extent to which a country signing an FTA

\footnotetext{
10 Slightly earlier agreements such as the EU-CARIFORUM Economic Partnership Agreement make different provisions in a separate chapter on "social issues", but contain a similar commitment to dialogue and the involvement of civil society organisations in the governance of this aspect of the agreement. It should also be noted that the EU's sustainable development agenda folds together labour provisions and environmental standards, which is not unproblematic (Harrison et al., 2018a). The EU's approach builds on its earlier unilateral GSP+ and Everything But Arms agreements which also contained requirements around ILO core labour standards, and for some (Marx, Ebert, Hachez and Wouters, 2017) provided a more robust way to deal with sanctioning against countries not fully meeting their obligations.

${ }^{11}$ Reference is also made to the ILO Decent Work Agenda and to promoting trade in a way that is conducive to enhancing full and productive employment, but there are no legal obligations that relate to this specific wording, thereby limiting the effectiveness of these references. In the recently negotiated CETA agreement with Canada and in the Commission's negotiating text on an EU-Mexico FTA, additional reference is made
} 
with the EU is required to adopt these fundamental conventions and this arises during the FTA negotiating process. For example, the EU-Moldova Association Agreement - including a Deep and Comprehensive Free Trade Area (DCFTA) - contains a commitment by both parties (the EU and the Republic of Moldova) which refers to "respecting, promoting and realising in their law and practice" the eight fundamental conventions, all of which had already been brought into the Republic of Moldova's legal framework prior to the establishment of the Association Agreement. ${ }^{12}$ By contrast, the EU-Korea FTA, which contains the same statement, also contains the following rider:

The Parties reaffirm the commitment to effectively implementing the ILO Conventions that Korea and the Member States of the European Union have ratified respectively. The Parties will make continued and sustained efforts towards ratifying the fundamental ILO Conventions as well as the other Conventions that are classified as 'up-to-date' by the ILO.13

This reflects the fact that the Republic of Korea has ratified only four of the eight ILO core conventions, and not the four relating to freedom of association and forced labour. Until 2017, there was little prospect that the Republic of Korea would move towards ratifying, but after the removal from office of President Park Geun-hye there was some indication at the time of writing (July 2018) that this may change under the Democratic Party which won the May 2017 presidential elections. However, controversies remain, including the ongoing imprisonment of a trade union leader and legal restrictions on freedom of association for teachers and public sector workers (ICTUR, 2018).

The template approach in these "new generation" agreements is most clearly reflected in the institutional mechanisms aiming to promote dialogue around sustainable development in the FTAs and to monitor implementation. These are summarised in Figure 1, which takes the case of the EU-Korea FTA and which has provided the format for most of the subsequent institutional structures established in EU FTAs. At the heart of this institutional framework is a commitment to engaging civil society in the process of overseeing and monitoring (Van den Putte, 2015; Harrison et al., 2018a). The inter-governmental Trade and Sustainable Development SubCommittee is reported to by two Domestic Advisory Groups (DAGs) which include representation of economic, social and environmental stakeholders in the EU and Korea, respectively. The DAGs can be involved in government consultations and are supposed to meet together at least once a year. This often combines with a Civil Society Forum (CSF), which includes members of the DAGs and the public at large. The recommendations arising from the CSF are either submitted directly to the parties to the agreement or through the DAGs. Should a dispute emerge on the intergovernmental Committee on Trade and Sustainable Development, parties must request consultations. If a satisfactory resolution is not forthcoming either party can request independent adjudication in the form of a Panel of Experts (PoE). The PoE submits its report to the parties, and this is also made available to the DAGs. The implementation of any PoE recommendation is monitored by the Committee on Trade and Sustainable Development. ${ }^{14}$ The focus of the EU's

to the promotion of "decent work" (including occupational health and safety, decent working conditions and labour inspection systems), CSR and ethical business practice, but again no legal obligations or requirements are set out in these spheres.

${ }^{12}$ Chapter 13, Article 365, paragraph 2. See Smith et al. (2017).

${ }_{13}$ Chapter 13, Article 13.4, paragraph 3.

${ }^{14}$ Thus far, there have been no instances of this process being invoked, despite considerable pressure from 
approach is therefore one of dialogue and providing voice to civil society, business and government actors in the governance of working conditions related to trade agreements.

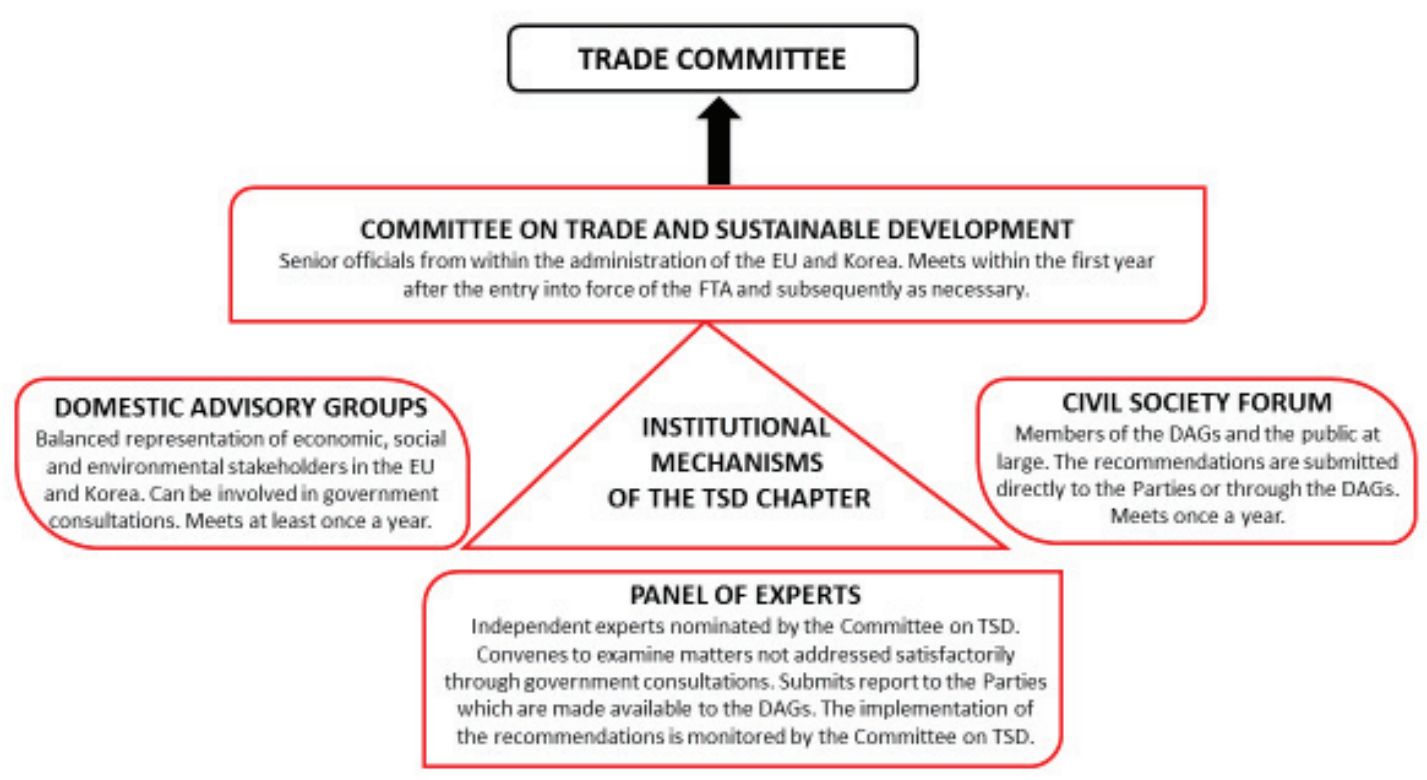

Figure 1.

Trade and sustainable development chapter institutional mechanisms in EU FTAs

This model of labour provisions in FTAs has been the focus of a number of studies. These include research focused on the legal aspects of the provisions, especially the ways in which substantive standards are formulated and procedural commitments are undertaken. Some compare the legitimacy and effectiveness of the provisions promoted through soft and hard law approaches (Abbott and Snidal, 2000; Karlsson-Vinkhuyzen and Vihma, 2009; Vogt, 2014), and others focus on the nexus between human rights and sustainable development obligations (Bartels, 2013). Existing research also includes studies focused on the institutionalisation mechanisms in the agreements and the ways in which multi-level spaces of governance are interconnected through legal obligations and the methods of interaction deployed in the agreements targeting different institutional structures (e.g. social partners, civil society, national governments, inter-partner committees, the EU, the ILO, etc.). The focus has been on inter alia the institutional mechanisms to elicit labour commitments in FTAs (Doumbia-Henry and Gravel, 2006; Van den Putte 2015), different levels of labour standards regulations in trade (Tsogas, 2001; Oehri, 2015), the role of the ILO in implementing a common set of labour provisions (Augustí-Panareda, Ebert and LeClercq, 2014; Peels and Fino, 2015), and the role of other provisions targeting national employment policies in trade agreements (Depelch and Ebert, 2014) as part of the EU's promotion of the social dimensions and impacts of trade policy (Orbie and Barbarinde, 2008; Orbie and Tortell, 2009; Van den Putte et al., 2013; Van den Putte and Orbie, 2015). An additional focus of research has been on assessing the effectiveness of labour standards in FTAs by quantifying the greater likelihood of

European and international trade unions to do so in the Korea context, and the European Commission has been very reluctant to engage such processes. 
a state fully protecting workers' rights after the coming into force of an agreement with the EU containing labour provisions (Postnikov and Bastiaens, 2014).

A separate set of approaches to the assessment of the effectiveness of labour provisions in trade agreements beyond the EU model seeks to establish explanatory patterns regarding the effects of labour standards on employment relations and labour rights' enhancement (Compa, 2001; Wells, 2006; Zhou and Cuyvers, 2011; Schrank, 2013; Hilary, 2014). More recently, research has focused on examining the effectiveness of the EU's "new generation" approach (Van den Putte, 2015; Ebert, 2016, 2017; Marx, Lein and Brando, 2016; Orbie, Martens, Oehri and Van den Putte, 2016; Orbie and Van den Putte, 2016; Harrison et al., 2018a). These studies concentrate on the degree to which the institutional mechanisms established by the agreements, and funding which flows to labour-related activities, are effective in promoting labour standards in trading partners. They point to significant operational failings, which have been noted by the Commission, in response to criticism by academics as well as civil society, European Parliamentary committees and trade unions (Harrison et al., 2018a,b).

However, no studies thus far have developed an analytical framework to consider the extent to which labour provisions in FTAs enhance working conditions in GVCs, especially where they are characterised by unequal inter-firm power relations. Given the increasing utilisation of such labour provisions in trade agreements, the role that FTAs are playing in cross-border economic integration via GVCs, and the significant evidence suggesting that this integration may be associated with worsening employment relations, there is an increasing need for such a framework. If the EU's labour standards provisions are to have a positive effect on working conditions and labour rights - as the EU states they should - they need to take into account the extent to which supplier firms located in countries producing goods for the EU market have a capacity to enhance labour standards. This depends on the forms of value chain governance and corporate power relations in operation in the production networks involved. It also includes, as we elaborate below, geo-political contexts and the national political economy of multi-scalar labour regimes. We argue that FTA labour provisions often neglect the complexities of the trade-labour nexus, including power relations in value chains. In investigating the articulation of value chains, geo-politics, multiscalar labour regimes and labour provisions governance in FTAs, the rest of this article sets out a framework for examining how the similar models of public labour governance in EU FTAs relate to the production of geographically and sectorally differentiated outcomes in labour standards due to economic power relations in private, inter-firm governance.

\section{Towards a Framework on the Trade-Labour Nexus}

A framework for understanding the intersection of labour provisions, national and geo-political contexts and GVC power relations in EU FTAs is provided in Figure 2. It sets out the forces influencing the capacity of supplier firms to enhance labour standards while operating in global value chains deepened by trade liberalisation. The framework turns on the proposition that the potential for using labour provisions contained in FTAs to drive progressive change in working conditions is differentiated on the basis of three primary forces. The first of these is the geopolitical-economic context, including the relative balance of commercial or other interests in establishing a trade agreement with the EU (Cowen and Smith, 2009; Glassman, 2011). The second factor is the national political economy, including national and local labour regimes and the regulatory frameworks established by states. Third are the power relations into which exportoriented supplier firms are integrated - that is, where a firm sits in the production network. However, the ways and degree to which each of these three forces intersect in shaping particular 
local outcomes of labour governance is a contingent question, related to the particular conjunctural dimensions of political forces, sectoral foci and labour politics in each case. The rest of this section draws upon contrasting illustrative examples from various EU trade agreements to illuminate the dynamics involved. The article's primary focus, however, is not these empirical examples but the wider analytical framework.

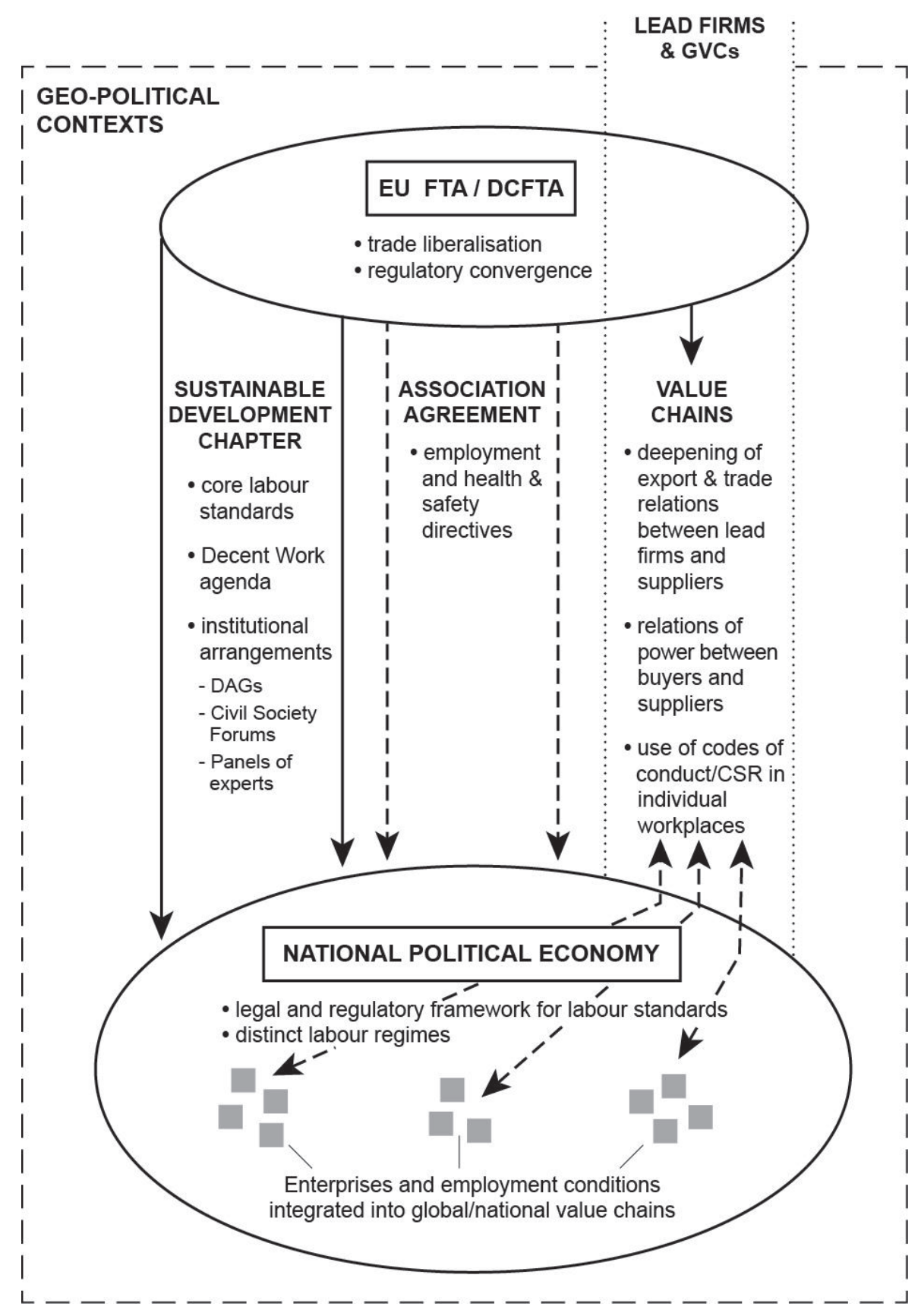

Figure 2. The analytical intersection of FTAs, labour standards and global value chain governance 


\section{Geo-political-economic contexts}

Figure 2 illustrates the contrasting governance domains connected within EU FTAs, which drive the differentiated effectiveness of labour provisions. On the one hand, the EU's trade liberalisation agenda is deeply rooted in the integration of third countries into the Single Market, integration into global value chains, and the promotion of regulatory convergence. One result is the externalisation of EU economic governance mechanisms and/or approximation to global standards in third countries (see, for example, Smith 2015b and Young 2015).

However, the geo-political and geo-economic contexts within which an FTA is embedded matter in important ways to the leverage that labour provisions in FTAs may have. For example, in situations when the EU has greater economic interests and the commercial imperatives to agree an FTA are strong, there may be greater scope on behalf of the non-EU state to negotiate how "deep" the labour provisions in the FTA are. This is illustrated in the case of the EU-Korea FTA. In that negotiating process the European Commission recognised the limits to which it could push the Korean government to accept full compliance with the ILO core conventions in order to complete the FTA negotiation process. ${ }^{15}$ In other words, the "normative" power of the EU to push forward its "European values" in the form of labour provisions is limited by constraints of its "market" power to secure a trade agreement (Manners, 2002; Damro, 2012).

On the other hand, states which are aiming to become members of the EU or which are integrated into the EU's neighbourhood policy - such as the Ukraine, Moldova and Georgia at the present time, where the FTA is part of a wider Association Agreement - have been required to achieve a higher level of regulatory convergence and approximation than in "standard" bilateral FTAs. Such states are required to adopt the employment and health and safety at work directives of the EU's acquis communautaire (the middle column of Figure 2), with potential to require deeper transformations of working conditions, in addition to ILO core conventions contained in the TSD chapters. ${ }^{16}$ This is just one part of the projection of EU norms and standards into neighbouring economies as part of the broader externalisation of economic governance by the EU in geopolitically neighbouring states. Consequently, the geo-political economic contexts within which respective FTAs are negotiated shape the scope and range of extant labour provisions ultimately contained in the FTAs.

\section{National political economy of multi-scalar labour regimes}

The national political economies of the signatory countries in which distinct labour regimes and different legal and regulatory frameworks for labour provisions are embedded also shape the ability of labour provisions in FTAs, which are focused on ILO core labour standards, to affect change in the material conditions of workers. The EU's FTAs are never "just" imposed, but are articulated with a national regulatory environment for labour that has emerged out of social struggles within each state, which manifest in the legal provisions and institutional mechanisms of a particular national state and its local state formations.

South Korea provides an example of the centrality of a domestic political economy in determining local labour regimes which limit the scope of labour provision implementation. As already noted, the EU-Korea FTA is a landmark agreement in setting the framework in relation to labour standards in all subsequent EU agreements. Industrial relations in Korea are determined

15 The Korean government has yet to endorse ILO conventions on freedom of association and forced labour.

16 Moldova had already adopted the eight ILO core conventions on the basis of earlier unilateral GSP+ and Autonomous Trade Preferences with the EU (Smith et al., 2017, 2018). 
less by lead firms outside of the country and more by domestic, family-controlled conglomerates with very close historical ties to the state (the chaebols). The chaebols, such as Hyundai and Samsung, are able to shape distinctive labour regimes, such as Samsung's infamous anti-trade union policy and Hyundai Motor Group's (HMG) refusal to recognise industrial unionism and its insistence on negotiating on an enterprise basis, which divides auto workers among its many subsidiaries and its domestic suppliers. At the same time, HMG auto workers are tightly organised and historically militant and remain leaders in - and more controversially, major beneficiaries of - the domestic labour regime (Koo, 2001; Lansbury, Kwon and Suh, 2006).

Nonetheless, HMG and other chaebol workers have not (yet) been powerful enough to insist on national ratification of the two ILO Conventions on freedom of association. This may be explained in part by the relatively low country-wide union density (around 10 per cent), but also by the culture of enterprise unions. Despite efforts by labour leaders, this culture means that rankand-file workers are more focused on immediate gains in individual workplaces as opposed to engaging in solidarity struggles with workers in completely different sectors, such as public educators. ${ }^{17}$ As such, current drivers of change in labour regimes in Korea are located in domestic social struggles, set in the geo-political context of Northeast Asia (Glassman and Choi, 2014), rather than derived from labour standards written into FTAs. ${ }^{18}$ This is not to suggest that the latter could not be recalibrated or redesigned to be better informed by and build upon these domestic struggles, but to argue that without doing so they are less likely to have an effect.

A contrasting example of the interactions between FTAs and national political economies is that of the EU-Moldova Association Agreement and Deep and Comprehensive Free Trade Area. Moldova has seen a variety of reforms to its labour legislation, building upon the legacies of those inherited from the Soviet Union. The most recent drive is towards labour market liberalisation and related reform of the Labour Code to allow greater labour market flexibility. In the context of the weakening power of trade unions, the drive towards liberalisation is led by business interests, such as the American Chamber of Commerce and the Employers' Confederation. This is establishing conditions in which informal employment is predominant, poverty wages prevail and labour inspection mechanisms are becoming more limited (Smith et al., 2017, 2018). The DCFTA and its labour provisions (which refer to ILO Core Labour Standards and not to these wider labour issues) seem unable to shape these processes directly, with important consequences for working conditions and labour market regulation in the country.

The ability of the EU's labour provisions in its FTAs to shape working conditions and labour standards must therefore be understood within the context of the national regulatory and political economic frameworks existing in third countries. We have pointed out how these frameworks result from struggles over the political economy of labour market regulation in particular cases. Analyses of the impacts of labour provisions thus need to consider these dimensions centre-stage. It may be that workers in partner countries will in the future seek to articulate with labour provisions in an EU FTA, as a resource or supplementary component of bottom-up struggles, but so far there is little evidence of this. Further, as discussed in our tracing of the trade-labour nexus earlier in this article, labour provisions in EU FTAs can also be seen in part as a top-down reaction to the bottom-up social opposition to trade liberalisation and its impacts (real or assumed) on

\footnotetext{
${ }^{17}$ For example, the Korean Teachers and Education Workers' Union (KTU) has consistently faced repression and bans by the Korean state since its formation in 1989.

${ }^{18}$ Korea also has an FTA with the United States, which includes labour standards that appear to have had no discernible effect on the ground.
} 
workers' rights and working conditions within the EU and, for some sections of European civil society, in trading partners.

\section{Global value chain governance and labour standards}

Central to the material restrictions of labour provisions in trade agreements (Barrientos et al., 2011: $310)$ is the third element of our framework: the power relations between lead firms and suppliers - "chain governance". The economic relations among firms may become more integrated as a result of the implementation of a trade agreement, but equally, depending on the industry and its relative exposure to the influence of trade policy, chain governance may be relatively untouched by an FTA. Either way, as is well-established in the research literature, inter-firm power relations differentiate the capacity of different types of firms and suppliers of lead firms to enhance labour standards (the right-hand column of Figure 2). The governance of power relations among firms establishes a differentiated landscape affecting the effectiveness of labour provisions in FTAs. This differentiation is the result of the particular pressures placed on suppliers by lead firms in GVCs which manifest in a variety of types of chain governance (Gereffi, Humphrey and Sturgen, 2005). Inter-firm governance recognises that a global value chain is not a linear space of production, distribution and consumption, but instead is articulated in various dispersed segments which are invariably positioned quite differently in the distribution of power relations between firms (Coe and Hess, 2007; Pickles and Smith, 2016). Furthermore, the inter-firm strategies deployed to capture value and externalise risk and cost can (and do) use forms of governance beyond the realm of the strictly economic (Havice and Campling, 2017).

Lead firm pressures can profoundly shape and potentially limit the possibilities for improvements in labour standards, which FTAs seek to achieve via institutional means. However, although the EU acknowledges the importance of GVCs in world trade, they are not explicitly addressed in the trade and sustainable development framework of the EU's FTAs, other than in somewhat loose commitments to corporate social responsibility. A good example is provided by the recently released negotiating texts of the European Commission on the proposed EU-Mexico and EU-Mercosur FTAs. Article 9 of the TSD chapters in both agreements discusses "trade and responsible management of supply chains" but only makes reference to promoting CSR and supporting dissemination and use of the Organisation for Economic Cooperation and Development (OECD) guidelines on multinational enterprises, ILO declarations on multinational enterprises and United Nations (UN) global compacts and guiding principles on business and human rights. Systematic comparative consideration of the interplay between these mechanisms and labour standards in FTAs is beyond the scope of this article, but suffice to say there is little substance included on mechanisms for effective implementation of such guidelines and declarations - a feature common to the EU's "promotional" approach (Smith et al., 2018).

As the signatory parties of an agreement are expected to channel their efforts towards the enforcement of labour standards, including in relation to export sectors, this goal appears exceptionally challenging when taking into consideration the fact that inter-firm power relations remain a key dynamic creating constraints on improving international labour standards.

Inter-firm power relations lead to a differentiated landscape across which firms have the ability to affect the implementation of international labour standards as set out in FTAs. It is, thus, necessary to appreciate the crucial role that forms of integration into inter-firm power relations play in structuring the boundaries around which enhancement of working conditions is possible. The ability of a supplier firm integrated into a wider GVC (and located in an economy with an FTA with the EU) to implement enhanced labour standards is thus not determined solely by public regulatory provisions of the FTA and their level of implementation by national governments. A 
fundamental determinant is the capacity of a supplier firm to implement change in working conditions and labour standards. In export sectors, such capacity is itself structured by the particular pressures and forms of governance that supplier firms experience from lead firm partners. This remains largely neglected in the FTA framework around trade and sustainable development.

Power relations between firms and their suppliers is a key dimension in understanding the ways in which lead firms seek to control costs and quality along the chain with differential outcomes for workers. In summary, Figure 3 elaborates five main attributes of inter-firm relationships within GVCs: the length of the contract relationship, production turnaround times, stability of production and contract relations, contract pressure, and payment terms (Kaplinsky and Morris, n.d.). Asymmetries in these attributes indicate whether inter-firm power relations in the value chain are likely to be more or less unequal. In the lower part of Figure 3, two different scenarios of potential variations in labour standards are shown. The causal relations between these two parts are not linear, but the relationships exist along a continuum of inter-firm power relations and outcomes for workers. They are mediated by national and local political-economic forces, including the capacity and willingness of the state to intervene in upholding labour standards and the ability and scope for organised labour to push for enhanced working conditions. More unequal inter-firm power relations are likely to result in a deterioration of the labour standards in the suppliers' working environment, although the severity of the decline depends on the labour regimes within which these firms are operating (Smith et al., 2018). Equally, less unequal inter-firm power relations may not be automatically transferred into improvements in labour conditions, but the impact of these factors will differ according to the labour regimes and the national political-economic contexts within which they operate. Other research confirms that variations in vertical power relations between lead and supplier firms in the value chain can have a direct impact on working conditions in supplier firms (Coe and Yeung 2015).

While global buyers can play a significant role in firm-level upgrading with their closest suppliers (Schmitz and Knorringa, 2000; Smith, 2015a), this does not automatically lead to improvements in labour conditions: "Simultaneous firm upgrading and improvements in labour conditions are most likely an exception to the rule, as they are limited to the initial phases of insertion in GVCs" (Knorringa and Pegler, 2006: 474). Although suppliers may be under increased pressure from lead firms to implement forms of industrial upgrading in value chains, they may also be squeezed by intense competition (Milberg, 2008).

As the examples from South Korea, above, also indicate, lead firms are not always external to the national economy regulated by labour provisions in an FTA. However, overall corporate power relations limit the ability of supplier firms to obtain a premium from industrial upgrading and to enhance working conditions. Kaplinsky (1998: 4) has suggested that this results in "immiserising growth" when "growing participation in industrial activities ... may in fact become associated with declining standards of living" (see also Arrighi, Silver and Brewer, 2003), and Smith (2015a) has shown how integration into EU-oriented production networks can differentiate forms of industrial and social upgrading and lead to economic insecurity. 


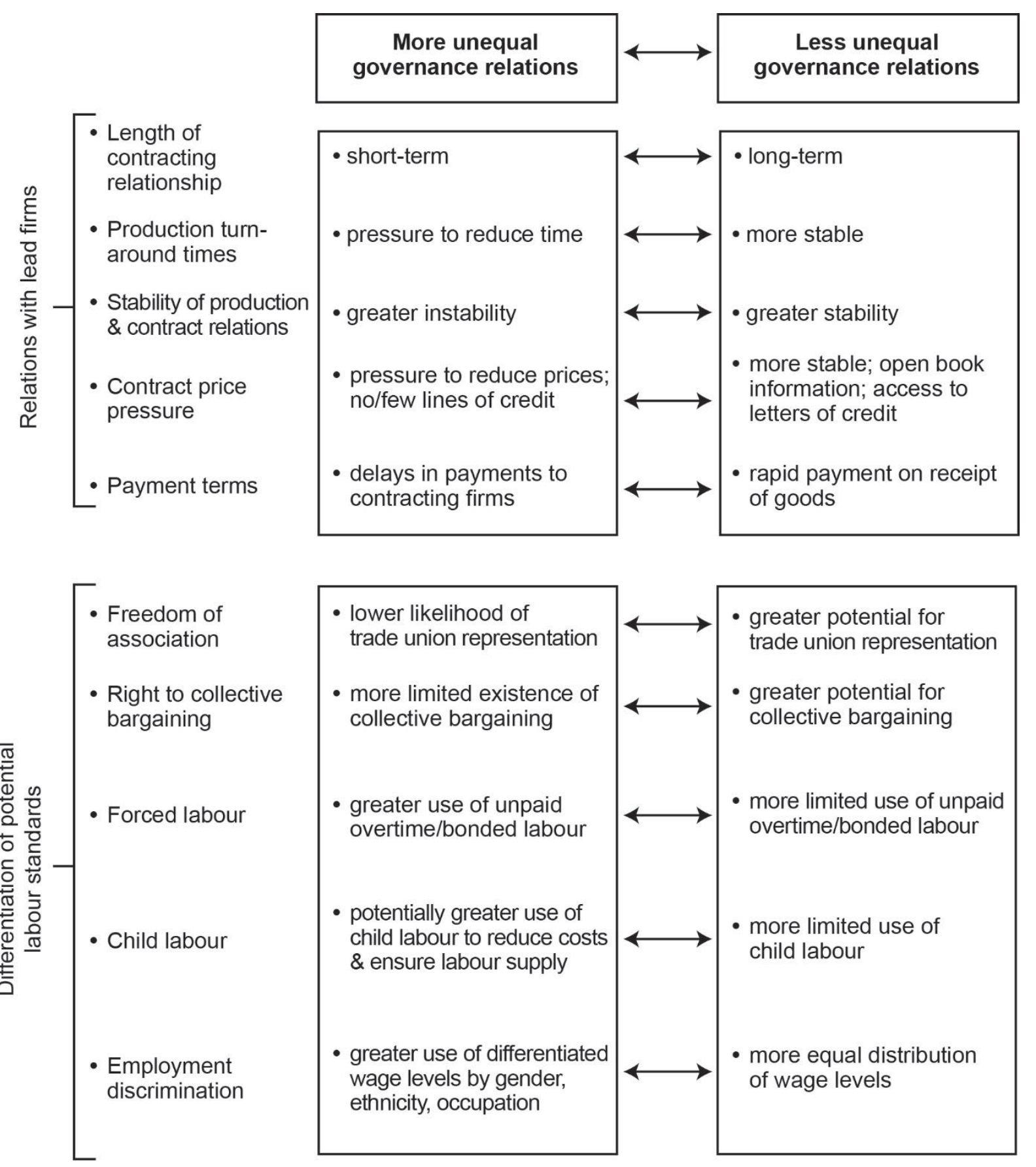

Figure 3. Global value chain governance and labour standards

(elaborated from Kaplinsky and Morris, n.d.)

\section{Interactions}

How these three forces of the framework interact will always be an empirical question, dependent upon particular histories, geographies, GVCs and even product types. Of course, FTAs themselves can facilitate the creation, expansion and/or intensification of GVCs and can even shape which segment grows the most in an economy. For example, the steady liberalisation of manufactured exports from Moldova to the EU in the context of the 2014 Association Agreement and DCFTA, preceded by earlier unilateral liberalisation under GSP+ arrangements, has led to deepening of 
production contracting and outsourcing arrangements in Moldova integrated into global value chains organised by lead firms in the EU (Smith et al., 2018). This trade liberalisation process has been part of the EU's geo-political agenda with western-facing states in its eastern neighbourhood in the context of struggles related to the projection of geo-political power in the former Soviet Union. It has also led to macro-regional integration via rules of origin in the wider pan-European and neighbouring country space which is deepening supply chain integration. Trade liberalisation has focused sectorally on labour-intensive segments of industry such as the clothing sector, not least due to the very low labour costs in Moldova and the tendency for the industry to relocate over time across Eastern Europe in search of lower-cost production sites (Pickles and Smith, 2016). The consequence is that, in the context of overall reduction in industrial employment in the country, the clothing segment has now established itself as the second most significant manufacturing-sector employer after food processing, growing from 9 per cent of employment in 2000 to 19 per cent in 2016. In this context, supplier firms in Moldova have become dependent on contract production for EU buyers. Purchasing practices have focused on squeezing of profit margins and value capture in local firms as EU buyers struggle to retain competitiveness in core EU markets. The consequence is a worsening of working conditions in supplier firms, which are increasingly under pressure to cut costs and compete for contracts with leading buyers (Smith et al., 2018). Thus, in turn, depending on national political-economic contexts, an FTA can serve to enhance firm power in a particular place through the growing economic significance of a particular sector, the growing influence of foreign direct investment (FDI) and their influence over domestic regulation. But the mechanisms found in the EU's labour provisions are insufficient to deal with the kinds of labour intensification issues found in export sectors like clothing dominated by the commercial power of lead firms. In this sense, value chain dynamics severely constrain the ability of supplier firms to comply with the substantive labour standards in the FTA.

Together, then, the analytical framework developed here indicates the importance of any set of labour provisions in an FTA taking into fuller consideration the dynamics of inter-firm power relations. It also indicates that consideration of the complex landscape of labour governance mechanisms in the global economy needs to understand the role that labour provisions in trade agreements are increasingly playing as an emergent, but not unproblematic, mechanism for global labour governance.

\section{Conclusion}

Building on the rich body of literature exploring the interdependencies between inter-firm power and workplace employment relations (Lund-Thomsen and Nadvi, 2010; Locke, 2013; Locke et al., 2013; Bartley and Egels-Zanden, 2015; Rossi, 2015), this article has developed an analytical framework to consider the linkages between institutional arrangements to promote labour standards through FTAs, and the unequal power relations between firms operating in global and national value chains. In doing so it has sought to address the limits of labour provisions in FTAs - as a new, emergent form of global labour governance - that were initially identified by Barrientos et al. (2011). The framework has highlighted the importance of recognising how FTAs deepen value chain integration and create a differentiated capacity of supplier firms to implement effective improvements in working conditions and labour standards contained in FTA labour provisions. However, and despite the significant literature on private labour governance mechanisms, there has been virtually no consideration of the articulation of labour provisions in public labour governance mechanisms such as free trade agreements with these inter-firm power relations. Given the increasing number and scope of such provisions within the world trade system, this is a gap 
that needs attention as part of an increasing recognition of the role that states play in the governance of global value chains. However, while models of outsourced private governance (Mayer and Phillips, 2017) have their limits, the centrality of states to FTA labour provision governance models are similarly constrained by the unequal material politics of value chain power relations - inequalities which are compounded by the very processes of value chain integration which FTAs seek to drive forward.

To this end, we have argued that the structures of private sector power relations in value chains shape the ability of labour provisions in the EU's inter-state FTAs to enhance working conditions. Using brief illustrative examples from labour-intensive export sectors, we have highlighted the interplay of power relations between supplier and lead firms - as these commercial arrangements become deepened through trade liberalisation - in constraining the extent to which labour standards clauses in FTAs can be an effective mechanism for enhancing labour rights in the world economy. Analytical attention thus needs to be applied to the nature of inter-firm power and governance relations in global value chains, which provide structure and shape the possibilities of corporate action by supplier firms in partner countries. Put differently, analytical attention must focus on the interplay of power relations between lead and supplier firms and GVC governance of social standards (i.e. private regulation) and labour standards embodied in the EU's FTAs (as a form of public regulation) as they both intersect with the capacity of supplier firms to implement effective improvements in labour conditions. ${ }^{19} \mathrm{It}$ is not, in other words, an either/or question as to whether the EU's public regulation via the labour provisions in its trade agreements is more effective than private standards. Analytical attention should focus on generating inter-dependencies and articulations between both dimensions, to drive positive interrelationships where one reinforces or enhances the other. Labour provisions within trade agreements need to be constructed in such a way that they can operate effectively in relation to different GVCs if they are to have an effect. That they have not yet done so is all too apparent in the literature on the failings of the EU's model of trade-labour governance in its FTAs.

\section{REFERENCES}

Abbott K.W. and D. Snidal (2000) Hard and Soft Law in International Governance. International Organization, 54(3): 401-419.

Alston P. (2004) "Core Labour Standards" and the Transformation of the International Labour Rights Regime. European Journal of International Law, 15(3): 457-521.

Anner M., J. Bair and J. Blasi (2013) Towards Joint Liability in Global Supply Chains. Journal of Comparative Labor Review and Policy, 35(1): 1-43.

Arrighi G., B.J. Silver and B.D. Brewer (2003) Industrial Convergence and the Persistence of the NorthSouth Divide. Studies in Comparative International Development, 38(1): 3-31.

Augustí-Panareda, J., F.C. Ebert and D. LeClercq (2014) Labour Provisions in Free Trade Agreements. ILO background paper. http://www.ilo.org/inst/projects/labour-standards-in-trade-and-investmentarrangements/WCMS 237940/lang--en/index.htm (accessed 24 September 2018).

Baglioni, E. (2018) Labour Control and the Labour Question in Global Production Networks: Exploitation and Disciplining in Senegalese Export Horticulture. Journal of Economic Geography, 18(1): 111-137.

Barrientos S., F. Mayer, J. Pickles and A. Posthuma (2011) Decent Work in Global Production Networks. International Labour Review, 150(3-4): 299-317.

19 See Locke (2013) for a similar argument in relation to the operation of private standards and codes of conduct. 
Bartels, L. (2013) Human Rights and Sustainable Development Obligations in EU Free Trade Agreements. Legal Issues of Economic Integration, 40(4): 297-313.

Bartley, T. and N. Egels-Zanden (2015) Responsibility and Neglect in Global Production Networks. Global Networks, 15: S21-S44.

Berg J.C. (ed.) (2003) Teamsters and Turtles? U.S. Progressive Political Movements in the 21st Century. Lanham, MD: Rowman \& Littlefield.

Bluth C. (2016) Attitudes to Global Trade and TTIP in Germany and the United States. Gütersloh: Bertelsmann Stiftung. https://www.bertelsmann-stiftung.de/fileadmin/files/BSt/Publikationen/GrauePublikation en/NW Attitudes global trade and T'TIP.pdf (accessed 12 April 2017).

Bove, A., A. Murgia and E. Armano (2017) Mapping Precariousness: Subjectivities and Resistance - An Introduction. In Mapping Precariousness, Labour Insecurity and Uncertain Livelihoods: Subjectivities and Resistance, edited by E. Armano, A. Bove and A. Murgia. London: Routledge.

Campling, L. (2016) Trade Politics and the Global Production of Canned Tuna. Marine Policy, 69: 220-228.

Campling L., J. Harrison, B. Richardson and A. Smith (2016) Can Labour Provisions Work beyond the Border? Evaluating the Effects of EU Free Trade Agreements. International Labour Review, 155(3): 357_ 382. doi: 10.1111/j.1564-913X.2015.00037.x

Campling, L. and E. Havice (2013) Mainstreaming Environment and Development at the WTO? Environment and Planning A, 45(4): 835-852.

Civic Consulting and Ifo Institute (2017) Evaluation of the Implementation of the Free Trade Agreement between the EU and its Member States and the Republic of Korea. https://static1.squarespace.com/static L5798bbd2be6594e06f727388/t/5950bcf0e4fcb533d1d45dd7/1498463505732/EUKorea+FTA+Interim+Technical+Report+Part+1+-+2017-06-19.pdf. (accessed 9 October 2017).

Coe, N.M. and M. Hess (2007) Global Production Networks: Debates and Challenges. Paper prepared for the GPERG workshop, University of Manchester, 25-26 January 2007. https://www.researchgate.net/publication/31359702 Introduction global production networks-debates and challenges (accessed 24 September 2018).

Coe, N.M. and H. Yeung (2015) Global Production Networks. Oxford: Oxford University Press.

Compa, L. (2001) NAFTA's Labor Side Agreement and International Labor Solidarity. Antipode, 33(3): 451467.

Cowen, D. and N. Smith (2009) After Geopolitics? From the Geopolitical Social to Geoeconomics. Antipode, 41(1): 22-48.

Curran, L. (2015) The Impact of Trade Policy on Global Production Networks. Review of International Political Economy, 22(5): 1025-1054.

Curran, L. and K. Nadvi (2015) Shifting Trade Preferences and Value Chain Impacts in the Bangladesh Textiles and Garment Industry. Cambridge Journal of Regions, Economy and Society, 8(3): 459-474.

Damro, C. (2012) Market Power Europe. Journal of European Public Policy, 19(5): 682-699.

Della Porta, D. (2005) The Social Bases of the Global Justice Movement: Some Theoretical Reflections and Empirical Evidence from the First European Social Forum. UNRISD Programme Paper Number 21. Geneva: UNRISD.

Delpech, Q. and F.C. Ebert (2014) Labour Market Concerns and Trade Agreements. ILO background paper. http://www.ilo.org/global/docs/WCMS 237711/lang--en/index.htm (accessed 24 September 2018).

Doumbia-Henry, C. and E. Gravel (2006) Free Trade Agreements and Labour Rights. International Labour Review, 145(3): 185-206.

Ebert, F.C. (2016) Labour Provisions in EU Trade Agreements. International Labour Review, 155(3): 407-433.

Ebert, F.C. (2017) The Comprehensive Economic and Trade Agreement (CETA): Are Existing Arrangements Sufficient to Prevent Adverse Effects on Labour Standards? International Journal of Comparative Labour Law and Industrial Relations, 33(2): 295-329. 
European Commission (2014) Opening the Windows: Commission Commits to Enhance Transparency. Press release, Strasbourg, 25 November. http://trade.ec.europa.eu/doclib/press/index.cfm?id=1205 (accessed 24 September 2018).

European Commission (2015) Trade for All. http://trade.ec.europa.eu/doclib/docs/2015/october/ tradoc 153846.pdf (accessed 24 September 2018).

Gereffi, G. (1994) The Organization of Buyer-driven Global Commodity Chains. In Commodity Chains and Global Capitalism, edited by G. Gereffi and M. Korzeniewicz. Westport: Praeger.

Gereffi, G., J. Humphrey and T. Sturgen (2005) The Governance of Global Value Chains. Review of International Political Economy, 12(1): 78-104.

Gibbon, R. and S. Ponte (2005) Trading Down. Philadelphia: Temple University Press.

Giegold, S. (2015) The Promised "Transparency" around TTIP has been a Sham. The Guardian, 31 August. https://www.theguardian.com/commentisfree/2015/aug/31/transparency-ttip-documents-bigbusiness (accessed 12 April 2017).

Glassman, J. (2011) The Geo-political Economy of Global Production Networks. Geography Compass, 5(4): 154-164.

Glassman, J. and Y.-J. Choi (2014) The Chaebol and the US Military-industrial Complex. Environment and Planning A, 46: 1160-1180.

Hale, A. (2005) Organising and Networking in Support of Garment Workers. In Threads of Labour, edited by A. Hale and J. Wills. Oxford: Wiley-Blackwell.

Harrison, J., M. Barbu, L. Campling, B. Richardson and A. Smith (2018a) Governing Labour Standards through Free Trade Agreements: Limits of the European Union's Trade and Sustainable Development Chapters. Journal of Common Market Studies, https://doi.org/10.1111/jems.12715.

Harrison, J., M. Barbu, L. Campling, F. Ebert, D. Martens, A. Marx, J. Orbie, B. Richardson and A. Smith (2018b) Labour Standards Provisions in EU Free Trade Agreements: Reflections on the European Commission's Reform Agenda. World Trade Review, https://doi.org/10.1017/S1474745618000204.

Hauf, F. (2015) The Paradoxes of Decent Work in Context. Global Labour Journal, 6(2): 138-155.

Havice, E. and L. Campling (2017) Where Chain Governance and Environmental Governance Meet. Economic Geography, 93(3): 292-313.

Haworth, N. and S. Hughes (1997) Trade and International Labour Standards. The Journal of Industrial Relations, 39(2): 179-195.

Hilary, J. (2014) European Trade Unions and Free Trade. Globalizations, 11(1): 47-57.

International Centre for Trade Union Rights (ICTUR) (2018) Open Letter to President Moon Jae-in from Daniel Blackburn, Director of the International Centre for Trade Union Rights, February 2018. http://www.ictur.org/pdf/ICTUR SKorea_Feb18.pdf (accessed 10 July 2018).

International Labour Organization (ILO) (1998) Declaration of Fundamental Principles and Rights to Work. Geneva: ILO.

International Labour Organization (ILO) (2008) Declaration on Social Justice for a Fair Globalization. Geneva: ILO.

International Labour Organization (ILO) (2013) Social Standards of Free Trade Agreements. Geneva: ILO.

International Labour Organization (ILO) (2016) Assessing the Effectiveness of Labour Provisions in Trade and Investment Agreements. Geneva: ILO.

Kaplinsky, R. (1998) Globalization, Industrialization and Sustainable Growth. IDS Discussion Paper 365. Brighton: Institute for Development Studies.

Kaplinsky, R. and M. Morris (n.d.) A Handbook of Global Value Chain Research. https://www.ids.ac.uk/ids/global/pdfs/VchNov01.pdf (accessed 30 September 2018). 
Karlsson-Vinkhuyzen, S.I. and A. Vihma (2009) Comparing the Legitimacy and Effectiveness of Global Hard and Soft Law. Regulation and Governance, 3: 400-420.

Knorringa, P. and L. Pegler (2006) Globalization, Firm Upgrading and Impacts on Labour. Tijdschrift voor Economischeen Sociale Geografie, 97(5): 470-479.

Koo, H. (2001) Korean Workers. Ithaca, NY: Cornell University Press.

Lansbury, R.D., S.-H. Kwon and C. Suh (2006) Globalization and Employment Relations in the Korean Auto Industry. Asia Pacific Business Review, 12(2): 131-147.

Law and Global Production Working Group (IGLP) (2016) Recognising the Constitutive Role of Law in Global Value Chains: A Research Manifesto. London Review of International Law, 4(1): 57-79.

Liu, W. and P. Dicken (2006) Transnational Corporations and "Obligated Embeddedness": Foreign Direct Investment in China's Automobile Industry. Environment and Planning $A$, https://doi.org/10.1068\%2Fa37206.

Locke, R.M. (2013) The Promise and Limits of Private Powver. Cambridge: Cambridge University Press.

Locke, R.M., B.A. Rissing and T. Pal (2013) Complements or Substitutes? Private Codes, State Regulation and the Enforcement of Labour Standards in Global Supply Chains. British Journal of Industrial Relations, 51(3): 519-552.

Lund-Thomsen, P. and N.M. Coe (2015) Corporate Social Responsibility and Labour Agency. Journal of Economic Geography, 15: 275-296.

Lund-Thomsen, P. and K. Nadvi (2010) Global Value Chains, Local Collective Action and Corporate Social Responsibility. Business Strategy and the Environment, 19: 1-13.

Malmström, C. (2015) Responsible Supply Chains: What's the EU doing? Speech delivered at the Conference on EU and Global Value Chains: Implementing Sustainable Business through Aid and Trade, Amsterdam, 7 December 2015. http://trade.ec.europa.eu/doclib/docs/2015/december/ tradoc 154020.pdf (accessed 30 September 2018).

Manners, G. (2002) Normative Power Europe. Journal of Common Market Studies, 40(2): 235-258.

Marx, A., F.C. Ebert, A. Hachez and J. Wouters (2017) Dispute Settlement in the Trade and Sustainable Development Chapters of EU Trade Agreements. Leuven: Centre for Global Governance Studies.

Marx, A., B. Lein and N. Brando (2016) The Protection of Labour Rights in Trade Agreements: The Case of the EU-Colombia Agreement. Journal of World Trade, 50(4): 587-610.

Mayer, F. and N. Phillips (2017) Outsourcing Governance: States and the Politics of a "Global Value Chain World". New Political Economy, 22(2): 134-152.

Milberg, W. (2008) Shifting Sources and Uses of Profits: Sustaining US Financialisation within Global Value Chains. Economy and Society, 37(3): 420-451.

Neilsen, J. (2014) Value Chains, Neoliberalism and Development Practice. Review of International Political Economy, 21(1): 38-69.

Newsome, K., P. Taylor, J. Bair and A. Rainnie (eds.) (2015) Putting Labour in its Place. London: Palgrave Macmillan.

Notes from Nowhere (2003) We Are Everywhere. London: New Left Books.

Oehri, M. (2015) Comparing US and EU Labour Governance Near and Far. Journal of European Public Policy, 22(5): 731-749.

Orbie, J. and O. Babarinde (2008) The Social Dimension of Globalization and EU Development Policy. Journal of European Integration, 30(3): 459-477.

Orbie, J., D. Martens, M. Oehri and L. van den Putte (2016) Promoting Sustainable Development or Legitimising Free Trade? Civil Society Mechanisms in EU Trade Agreements. Third World Thematics: $A$ TWQ Journal, 1(4): 526-546.

Orbie, J. and L. Tortell (eds.) (2009) The EU and the Social Dimension of Globalization. London: Routledge. 
Orbie, J. and L. van den Putte (2016) Labour Rights in Peru and the EU Trade Agreement. Austrian Foundation for Development Research Working Paper 58. http://www.oefse.at/fileadmin/content/Downloads/ Publikationen/Workingpaper/WP58_Peru_Study.pdf (accessed 1 December 2016).

Pattenden, J. (2016) Working at the Margins of Global Production Networks: Local Labour Control Regimes and Rural-based Labourers in South India. Third World Quarterly, 37(10): 1809-1833.

Peels, R. and M. Fino (2015) Pushed out the Door, Back in through the Window. Global Labour Journal, 6(2): 189-202.

Pickles, J. and A. Smith (2016) Articulations of Capital. Oxford: Wiley-Blackwell.

Postnikov, E. and L. Bastiaens (2014) Does Dialogue Work? The Effectiveness of Labour Standards in EU Preferential Trade Agreements. Journal of European Public Policy, 21(6): 923-940.

Rossi, A. (2015) Better Work: Harnessing Incentives and Influencing Policy to Strengthen Labour Standards Compliance in Global Production Networks. Cambridge Journal of Regions, Economy and Society, doi: $10.1093 /$ cjres/rsv021.

Routledge, P. (2000) “Our Resistance will be as Transnational as Capital”: Convergence Space and Strategy in Globalising Resistance. GeoJournal, 52: 25-33.

Schmitz, H. and P. Knorringa (2000) Learning from Global Buyers. Journal of Development Studies, 37: 177205.

Schrank, A. (2013) From Disguised Protectionism to Rewarding Regulation. Regulation and Governance, 7: 299-320.

Smith, A. (2015a) Economic (In)Security and Global Value Chains. Cambridge Journal of Regions, Economy and Society, 8(3): 439-458.

Smith, A. (2015b) Macro-regional Integration and the Externalisation of Economic Governance on the European Union's Borders. Transactions of the Institute of British Geographers, 40(4): 507-522.

Smith, A., M. Barbu, J. Harrison, B. Richardson and L. Campling (2017) Labour Provisions in the European Union - Republic of Moldova Association Agreement. In Handbook on Assessment of Labour Provisions in Trade and Investment Agreements, edited by International Labour Organization. Geneva: ILO.

Smith, A., M. Barbu, L. Campling, J. Harrison and B. Richardson (2018) Labor Regimes, Global Production Networks, and European Union Trade Policy: International Labor Standards and Export Production in the Moldovan Clothing Industry. Economic Geography, doi: 10.1080/00130095.2018.1434410.

Spener, D., G. Gereffi and J. Bair (2002) Introduction, in Free Trade and Uneven Development, edited by G. Gereffi, D. Spener and J. Bair. Philadelphia: Temple University Press.

Stephenson, S. (2016) Trade Governance Frameworks in a World of Global Value Chains: Policy Options. E15 Expert Group on Global Value Chains: Development Challenges and Policy Options - Policy Options Paper. Geneva: E15 Initiative ICTSD and World Economic Forum.

Tran, A., J. Bair and M. Werner (2017) Forcing Change from the Outside? The Role of Trade-Labour Linkages in Transforming Vietnam's Labour Regime. Competition and Change, 21(5): 397-416.

Tsogas, G. (2001) Labour Regulation in a Global Economy. New York: M.E. Sharpe.

Van den Putte, L. (2015) Involving Civil Society in Social Clauses and the Decent Work Agenda. Global Labour Journal, 6(2): 221-235.

Van den Putte, L., F. Bossuyt, J. Orbie and F. de Ville (2013) Social Norms in EU Bilateral Trade Agreements. In Linking Trade and Non-Commercial Interests, edited by T. Takacs, A. Ott and A. Dimopoulos. Den Haag: TMC Asser Institute.

Van den Putte, L. and J. Orbie (2015) EU Bilateral Trade Agreements and the Surprising Rise of Labour. The International Journal of Comparative Labour Law and Industrial Relations, 31(3): 263-284.

Vogt, J. (2014) Trade and Investment Arrangements and Labour Rights. In Corporate Responsibility for Human Rights Impacts, edited by L. Blecherr, N. Kaymar Stafford and G. Bellamy. Chicago: American Bar Association. 
Wells, D. (2006) "Best Practice" in the Regulation of International Labor Standards. Comparative Labor Law and Policy Journal, 27(3): 357-376.

Werner, M., J. Bair and V. Ramiro Fernández (2014) Linking Up to Development? Global Value Chains and the Making of a Post-Washington Consensus. Development and Change, doi: 10.1111/dech.12132.

Wilkinson, R. and S. Hughes (2000) Labour Standards and Global Governance. Global Governance, 6(2): 259277.

Young, A. (2015) Liberalizing Trade, Not Exporting Rules: The Limits to Regulatory Co-ordination in the EU's “New Generation” Preferential Trade Agreements. Journal of European Public Policy, 22(9): 12531275. doi: 10.1080/13501763.2015.1046900.

Zhou, W. and L. Cuyvers (2011) Linking International Trade and Labour Standards. Journal of World Trade, 45(1): 63-85.

\section{ACKNOWLEDGEMENTS}

This article arises from research undertaken as part of an ESRC-funded project entitled "Working Beyond the Border: European Union Trade Agreements and Labour Standards" (award number: ES/M009343/1). Previous versions of this paper were presented at the workshop on Global Production Networks and Social Upgrading: Labour and Beyond, University of Manchester, May 2016, and at the $10^{\text {th }}$ European Urban and Regional Studies Conference, Chania, September 2016. We are very grateful to participants at these meetings for their comments, to the reviewers and editors of the Global Labour Journal, and to Ed Oliver at Queen Mary University of London for drawing the figures.

\section{BIOGRAPHICAL NOTES}

Mirela BARBU is Lecturer in Global Supply Chains at Queen Mary University of London. Her research focuses on the global supply chain of textiles and clothing, with a focus on industrial change and supplier upgrading. [Email: m.barbu@qmul.ac.uk]

LiAm CAMPLING is Reader in Political Economy at the School of Business \& Management, Queen Mary University of London. He works on international trade, global production and labour regimes. [Email: 1.campling@qmul.ac.uk]

ADRIAN SMITH is Professor of Human Geography and Dean for Research (Humanities and Social Sciences) at Queen Mary University of London. His research focuses on labour and global production and clothing industry production networks, and he has conducted extensive research in several East-Central European countries. [Email: a.m.smith@qmul.ac.uk]

JAMES HARRISON is a Reader in the School of Law at Warwick University. His research is in the area of international economic law and its intersections with human rights, labour rights and sustainable development. [Email: J.Harrison.3@warwick.ac.uk]

Ben Richardson is Associate Professor in International Political Economy at Warwick University. His research is on international trade and development with a focus on agricultural commodities. [Email: B.J.Richardson@warwick.ac.uk] 